\title{
The Practical Plight and Innovation Path of College Educational Management in the New Situation
}

\author{
Li Feng \\ School of Arts, East China University of Technology, China
}

Keywords: College educational management; Practical plight; Innovation path

\begin{abstract}
The 21st century is the rapid development period of science technology and social economy. Education, as the booster of productivity, must positively develop at the same pace as the society. college education has entered the critical period of radical reform and development, but the practical problems, such as the stale management contents, low management efficiency, the unsound management system, the single management method and the lack of scientificity are also restricting its reform and advancement to certain degree, and the current college managers must settle these problems to render a perfect management effect.
\end{abstract}

\section{Introduction}

The innovation path of the college educational management in the new situation includes the innovating college management concept, upgrading educational management system, realizing diversified educational management method and improving educational management system.

\section{The Significance of Innovating College Educational Management in the New Situation}

Conforming to the Changing Situation of Social Development and the Current Educational

Reform. In recent years, social economy is developing at a fast pace, especially with the advent of the internet era and its widespread impact on the whole society, it is impacting people's mind and ideas in all aspects and has produced various knowledge theory and concepts, creating a new situation with diversified thoughts. Under the impact of this new situation and thoughts, colleges are facing multiple chances coexisted by rigid challenges. At present, the society demands colleges to get used to the situation as soon as possible to avoid being eliminated in this new historical period. However, the traditional educational management concepts, educational management systems and contents, no longer well serving the development of the economy and society, are also hindering the advancement of the colleges and even begin to exercise some side effects. Tat requires the colleges to keep up with times, accelerate the steps of reform, positively conform to the development of modern society and the tide of national educational reform, seek its own development path and cultivate more excellent talents for national socialist modernization in this new historical situation.

The Inevitable Movement Due to the Currently Adequate Educational Management in College. In recent years, the colleges have seen some progress in the aspects of educational thought, management system and contents through all kinds of positive reforms to better suit modern society and economic situation. However, there is still a long way to go for the national colleges to get link with world elite universities. They have to face multiple problems in their management which can badly affect the teaching quality, learning efficiency and the cultivation of innovative college students. Under the influence of the traditional economy and thoughts, the colleges just find a hard situation to implement the people-oriented educational principle in their practical management work, and that has dragged the step of innovation and creativity to certain degree. Meanwhile, many tasks cannot be finished and many problems are hard to be settled within the expected schedule for the unprofessional quality of the management team, a plight that inevitably hinders the development of the society. 


\section{The Practical Plight of Educational Management in Our National Colleges at Present}

The Practical Plight of Our National College Educational Management in Terms of Ideology and Politics. The educational concept in terms of ideology and politics is the first matter of educational management. Under the long impacts of social ideology and the special development of the society, our educational management is mainly inclined to the standard values of the social subjective in the specific process of educational management, seeking start more from social perspectives but having ignored individual value pursuit and the demands for overall development. With the rapid development of social economy, the teachers and college students in the new era are getting increasing influence of the outside society, and the college students are paying more and more attention to their future development and mode of survival.

Meanwhile, the college educational management in terms of ideology and politics are too formalized and the contents cannot suit the development of modern college students with the new ideas from science innovation. The students just finish the required college class hours as routine, a waste of educational teaching resource. In addition, it brings little effect on modern college ideological and political education. The traditional college educational management concept can obviously no longer keep up with the development steps of the times, for the traditional educational management emphasizes too much how the individuals suit the society, and ignores their own value embodiment and the cultivation of subjective initiative and creativity. When the individuals are under the impact of social environment, they will also react upon it and create a contradiction between educational management, implementation and the educatee, the contradiction that will inevitably affect the implementation of the whole college educational management. Therefore, it is imperative to change the educational management thoughts in aspects of ideological and political education.

The Practical Plight in Terms of Our College Management Staff. With the rapid development of market economy, the thoughts of the network era has been deeply rooted in people's mind and the students can be exposed to the new teaching mode and concepts even at little age. However, most of the colleges remain move slowly along the journey of reform. Seriously affected by the traditional economic system and ideas, our colleges are still on-sided and subject to the command of government, and most of them do not even have their sound educational management idea and give too much emphasis on administerization. They cannot efficiently handle some problems but can only copy the past practice with too much administrative aspiration; they have rigid and inflexible academic atmosphere, unable to give full play to the teachers and student's innovation consciousness and enthusiasm. All these have obstructed the overall development of the colleges.

The much too simple management method and hard to implement people-oriented management thought

Under the impact of the traditional ideas, college management remains caught in the ruts that are too dogmatic, modeled and unitized with serious administrative ideas and ignorance of the students' subjective position. In the process of management, too much emphasis is paid to the past management standards and norms with some administrative interference, leading a low democracy and humanization degree in educational management. The situation is rather harmful to the reform of college educational reform. Meanwhile, the college managers shall have a service purpose and have all the teachers and students as their service objects. However, the college just put the cart before the horse, and at present, they cannot make sure the equality between the managers and the managed, instead they even put the managers high above the managed. Even though some managers can realize the people-oriented modern educational concept, the huge inequality just makes it quite hard for the interaction and communication in teaching management, and finally drags the healthy development of the colleges.

The Backward Management Concept of the Managers Hard to Keep Up with the Times. Despite the accelerated educational pace in our country, there remains a big gap for the old 
management concepts and methods of our education managers and the lack of scientificity in management. These problems remain on the dominant position in the whole management work. Meanwhile, the college educational managers suffer from backward management concept and bad service consciousness, unable to make scientific and effective planning in face of the current teaching plan. At present, there is even a widespread deficiency in a group of elite educational management team, since most of the educational managers right now lack professional education knowledge and educational management ability. As a result, they cannot work out specific and feasible educational and teaching management tasks based on the actual conditions of the colleges and the social demands, and meanwhile they cannot give a scientific and reasonable analysis on the practical problems in education and teaching. In face of the advanced educational management mode, they have no ideals on how to learn and copy from professional perspectives, getting the whole educational process out of its original vitality, and nipping the buds of flexible academic innovation and creativity cultivation in the process of teaching.

\section{The Innovative Thinking on Our College Educational Management in the New Situation}

The colleges are facing rigorous practical issues in educational management amidst the fast advancement of the society. As college educational managers, they must make a rational analysis on the current plight, get the issues settled one by one and improve educational management work to grasp the opportunities for a long development in this period of historical opportunity. In this circumstance, "innovative reform" also becomes the top priority in reality.

Strengthen the Construction of College Educational Management in Political and Ideological Education. Strengthening political and ideological education is an important aspect of our education reform. College educational management cannot go without the guidance of political and ideological education. The trend of diversification of the society is going clearer, and the colleges, as the talent cultivation base of our country, are shouldering the mission of cultivating socialism construction talents. In terms of educational management

Strengthening political and ideological education is the requirement of our future and the times. It has far-reaching guidance significance in helping modern students set up correct socialist outlook on life and values.

In the process of education, college educational managers shall focus on practice, implement people-oriented educational concept, communicate with the mass teachers and students to know their real ideas and start all their work from the perspectives of the teachers and students. Meanwhile, strengthen the courses of ideology and politics, and make sure the practical significance of the courses, instead of purely impart empty thoughts and dogmas. In terms of teaching contents, make sure the contents are flexible and keep pace with the times, introduce the topics that can interest the teachers and students and reinforce the education for the students' idea of socialist core values in practical sense.

The Innovation on College Management Concepts. The current society has long been out of the limits of planning economy, and the college education, under the serious impact of market economy, must stand in the fore of the times and keep the same pace with the society and economy. Therefore, at the time of educational reform, the colleges shall dear to get rid of the traditional teaching concepts and seek mind emancipation. Starting from the practice, focus on the tide of social and economic advancement, stick to the new people-oriented teaching and training concepts, emphasize people's subjective initiative and creativity, and build a diversified and people-oriented educational management system.

Carefully implement people-oriented concept, identify the reasonable educational management objective, enrich the essence of management, bring to life college campus cultural atmosphere, improve the cultural level and the comprehensive quality of the college students, and cultivate their humanistic spirit and the correct ideology to realize their healthy and sustainable development. 
Strengthen the Construction of Educational Management Team. A strong educational management team is needed to realize the rapid transition and reform of colleges in the new era and strengthen educational management team construction. Strengthening college educational management construction is just to strengthen the construction of education management team in the final analysis. In the process of reform, the colleges shall organize a group of management staff with high comprehensive quality, rich management experience strong sense of responsibility, solid professional quality and high service consciousness. In their practical work, they shall identify the work contents of the management staff and endow the corresponding rights; and in the practical operation, a scientific incentive mechanism shall be established to encourage the innovative consciousness of the management staff, increase educational management and training investment to get the management team equipped with the advanced educational management concepts and modes. Meanwhile, the colleges shall also positively carry out the walk-out and bring-in strategy to absorb the excellent management talents and make a stronger educational management team. In this way can the college educational management reform and work efficiency be ultimately improved at the greatest extent.

The smooth going of college educational reform requires not only the abilities and qualities of the educational managers, and also the innovation on system. once the educational management system is established, it will show its stability which can ensure the teachers and students a stable behavior expectations and make sure the establishment and maintenance of the educational management system.

System innovation shall keep the same pace with the times. In real life, the spatial change of the educational management system is closely bond to the reform and change of the whole social system. at the same time, it also has a close link with the real system environment. The college educational management system reform shall depend on both the inherent conditions of the colleges and also measurement of the external system environment mechanism, such as national educational teaching guideline. College campus educational management system shall keep leapfrog advancement and also keep consistent with our national reality. Under the national policy, the colleges shall make sure scientific and healthy system construction, improve themselves and promote the order progress of educational management system reform.

However, from the perspective of development, any system will correspondingly change with the development of the society. The establishment of the educational management system shall also constantly conform to the change of the current social development and educational reform, and get corresponding adjustment and improvement

\section{Conclusion}

We need to further improve and strengthen the construction of the educational management quality system to make sure the smooth development of the scientific and humanistic modern educational management in colleges under the systematic situation. The quality management system can be established as an all-dimension and diversified evaluation system, including educational level, student innovation and creativity, and the teachers' teaching and management level. The overall evaluation can realize positive communication, democratic sharing and the improvement of efficiency. Carry out people-oriented policy, put the students to the master position of education, give full play to their creativity and innovative capacity, build colleges a harmonious and active innovation base in this new era of great development of social economy.

\section{References}

[1] Wang Fenlei, The practical Plight and Innovation Path of College Educational Management under the New Circumstance [J], Liaoning Agricultural Vocational Technical Institute Journal, 2014, issue 3:54-55. 
[2] Mo Liping, The practical Plight and Innovation Path of College Educational Management under the New Circumstance [J], Liaoning Agricultural Vocational Technical Institute Journal, 2014, issue 24:54-55.

[3] Chen Peini, He Guiming, Zheng Qingzhong, The Exploration about the Application of Knowledge Management in College Common Sense Education [J], China Science and Education Innovation magazine, 2008,16:34.

[4] Yang Jun, The Application of the Characteristic Functions of Sina Microblog in College Student Education and Management [J]. Cultural Education Materials, 2015,03:64-65.

[5] [5] Zhou Yanbo, College Innovative Education [M], Science Press, - 2011:15-18.

[6] Local College Education Informatization Construction and Application Innovation [M], Zhang Deshi, Southeast University press-2011:12-15. 